\title{
Soil fertility characterisation of teak (Tectona grandis L.f.) plantations in Central America
}

\author{
Jesús Fernández-Moya ${ }^{\mathrm{A}, \mathrm{B}, \mathrm{E}}$, Alfredo Alvarado ${ }^{\mathrm{B}}$, Rafael Mata ${ }^{\mathrm{B}}$, Helga Thiele ${ }^{\mathrm{B}}$, \\ Jose Manuel Segura ${ }^{\mathrm{C}}$, Edwin Vaides ${ }^{\mathrm{C}}$, Alfonso San Miguel-Ayanz ${ }^{\mathrm{A}}$, \\ and Miguel Marchamalo-Sacristán ${ }^{\mathrm{D}}$ \\ ${ }^{A}$ Dpto. Silvopascicultura. E.T.S.I. Montes, Universidad Politécnica de Madrid (UPM), \\ Ciudad Universitaria s/n. 28040 Madrid, Spain. \\ ${ }^{B}$ Centro de Investigaciones Agronómicas, University of Costa Rica (CIA-UCR), Costa Rica. \\ ${ }^{\mathrm{C}}$ Green Millennium Company, Guatemala. \\ DDpto. Ingeniería y Morfología del Terreno, Universidad Politécnica de Madrid (UPM), \\ Ciudad Universitaria s/n. 28040 Madrid, Spain. \\ ${ }^{E}$ Corresponding author. Email: jesusfmoya@gmail.com
}

\begin{abstract}
Teak (Tectona grandis L.f.) is an important species in the worldwide quality tropical hardwood sector, which has gained significance in Central America since the first large plantations were established in the 1980s. The present work is a descriptive study that aims to: (1) analyse and characterise the general soil patterns which may be influencing teak plantations in Central America; (2) assess differences between countries and sub-regions; (3) create a global framework to help contextualise the soil fertility analyses conducted at sub-regional or farm level, and (4) determine the main problems associated with soil fertility in the region. Soil fertility was measured at 684 sites in Costa Rica, Guatemala and Panama. Although teak is considered to be a species with high soil nutrient requirements, and high fertility is usually assumed in teak plantations, the results show that this species has been planted in a wide variety of soils, including many with serious fertility problems (e.g. Ultisols and perhaps Oxisols) or with added difficulties due to their physical properties (e.g. Vertisols). The present analysis reveals a general K deficiency in the Central American teak plantations, where P deficiency and acidity toxicity are also relatively common problems. These soil fertility problems probably stem from poor site selection by forest managers in the 80 s and 90 s. Hence, although soil fertility is carefully evaluated when most teak plantations are established today, managers have to deal with soil fertility deficiencies in many sites where teak was established some years ago.
\end{abstract}

Additional keywords: forest nutrition, forest plantations, forest soils, planted forests, site selection, tropical soils.

Received 11 September 2014, accepted 29 January 2015, published online 30 June 2015

\section{Introduction}

Teak (Tectona grandis L.f.) is an important species in the worldwide quality tropical hardwood sector, with a total planted area of $4.3 \times 10^{6}$ ha (Pandey and Brown 2000; De Camino et al. 2002; Kumar 2011; Kollert and Cherubini 2012). Teak has been extensively planted in Central America (132770 ha), mainly in Panama, Costa Rica and Guatemala (55000; 31500 and 28000 ha; respectively) and it has also been introduced in El Salvador, Nicaragua, Honduras and Belise (9760; 7960; 450 and 100 ha, respectively) (Kollert and Cherubini 2012). Despite the relatively minor importance of Central American plantations in the worldwide teak sector, teak plantations have had quite far-reaching socioeconomic and environmental effects in Central America due to the small size of the countries. Panama is the third in terms of area dedicated to teak plantation relative to the size of the country, while Costa Rica is the fifth and El Salvador, the ninth (Kollert and
Cherubini 2012). Arias (2004) highlighted the fact that forest plantations (especially teak plantations) established by large or medium-sized companies not only provide environmental services, but also play an important role in the sustainable development of countries like Costa Rica, creating employment in rural areas where few other job opportunities exist. In addition, many small landowners have also planted teak across the region, and usually manage their plantations as a complementary crop alongside other land uses within their farms.

Nieuwenhuyse et al. (2000) estimate that around $70 \%$ of the landscape should be covered by teak plantations in order to maximise the regional income of their study area in the Caribbean lowlands of Costa Rica. These authors report that the production of a valuable timber species, such as teak, is more profitable than fast-growing low-quality wood species, such as Gmelina arborea, or other land uses, such as basic grain and 
beef cattle ranching. Due to the high profitability of teak plantations (Nieuwenhuyse et al. 2000; Pandey and Brown 2000; De Camino et al. 2002), Central America is among the regions that have seen the greatest increase in area dedicated to teak plantations. In 2010, the area occupied by teak plantations in Guatemala was 16 times greater than in 1995; in Panama the area was 14 times larger, 13 times larger in Nicaragua, 5 times larger in El Salvador and twice as large in Costa Rica (Kollert and Cherubini 2012). These trends in Central America are even more marked if Latin America is considered as a whole, since large increases have been reported in Ecuador and Brasil (Kollert and Cherubini 2012), two countries where a sharp increase in the area occupied by teak plantations is expected over the next few years.

The present work is a descriptive study which aims to: (1) analyse and characterise the general soil patterns which may be influencing teak plantations in Central America; (2) assess differences between countries and sub-regions; (3) create a global framework to help contextualise the soil fertility analysis conducted at sub-regional or farm level, and (4) determine the main problems associated with soil fertility and use the findings to define further lines of research in the near future. No attempt is made in this study to analyse the relationship between soil fertility and growth, as this line of investigation is currently being addressed elsewhere. However, the rationale for the present study is the need to gain a clearer understanding of teak growth performance at a regional scale.

\section{Materials and methods}

\section{Study area}

A set of teak (Tectona grandis L.f.) plantations was selected across Central America: Guatemala, Costa Rica and Panama (Fig. 1); from $17^{\circ} \mathrm{N}$ in the Petén region of Guatemala to $8^{\circ} \mathrm{N}$ in the southern region of Costa Rica and the Panama Canal Watershed. Although the climate varies across the large study area, most of the study sites are in tropical or subtropical moist forest (mean annual rainfall of $2000-4000 \mathrm{~mm}$ with 4-6 dry months) and tropical or subtropical wet forest (mean annual rainfall of $4000-8000 \mathrm{~mm}$ with $0-3$ dry months) life

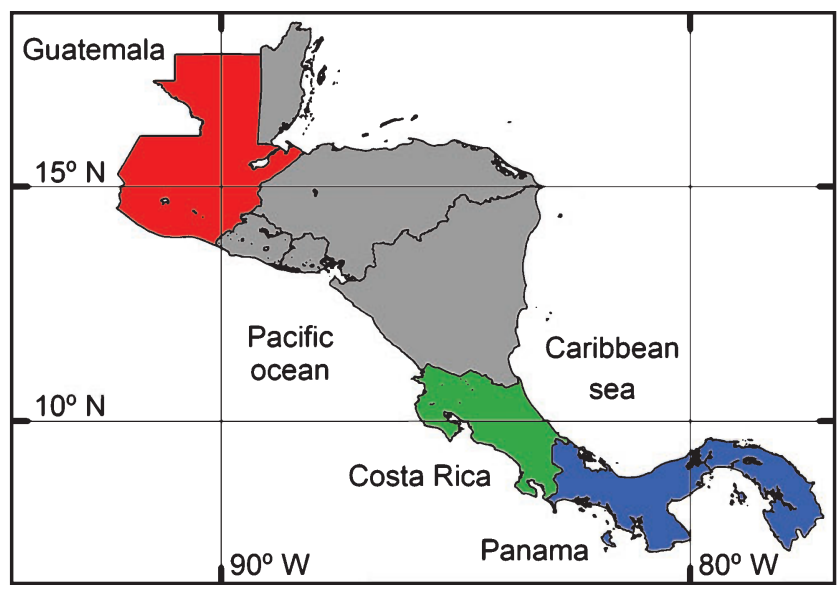

Fig. 1. General location of the countries of the study (Guatemala, Costa Rica and Panama) in Central America. zones, according to the Holdridge (1967) classification. A wide variety of USDA soil orders were also found throughout the study area, including Inceptisols, Entisols, Vertisols, Andisols, Alfisols, and Ultisols.

Most planted teak forests in Central America have been established on land previously used for beef cattle ranching, although some sites had been used for agricultural crops such as corn or bananas. The previous overgrazing of the land has generally led to soil compaction and erosion in many planted teak forests in the region. This degradation has sometimes been wrongly attributed to teak establishment and in many cases has caused high land preparation costs and a decrease in the potential site productivity.

Management of planted teak forests varies depending on whether they are woodlots belonging to small landowners or large-scale company-owned plantations. However, there are general patterns that are common to most planted teak forests in Central America. The rotation period is usually around 20-25 years, with an expected commercial volume of $100-150 \mathrm{~m}^{3} \mathrm{ha}^{-1}$ at the final harvesting. Management of these plantations consists of continuous silvicultural activities: land preparation, fertilisation and liming during establishment (at variable dosages and formulae depending on the company), weed control, pruning and thinning (from $\sim 816-1111$ trees ha $^{-1}$ to $150-200$ trees $^{-1}$ at final felling); although some of these activities are not always performed, depending on the management intensity adopted by the owner or manager.

\section{Data collection, transformation and statistical analysis}

A compilation of different local scale soil studies in which some of the authors had participated was assembled. Soil fertility information from 684 sites was collected: 299 in Costa Rica, 257 in Guatemala and 128 in Panama. Topsoil $(0-20 \mathrm{~cm})$ and subsoil $(20-40 \mathrm{~cm})$ information was available for these sites and was averaged to estimate soil fertility at 0-40 cm. The following soil attributes were used for the present analysis: $\mathrm{pH}$, available $\mathrm{P}$, available cations $(\mathrm{Ca}, \mathrm{Mg}, \mathrm{K}$ and acidity) and their derived attributes: effective cation exchange capacity (ECEC), $\mathrm{Ca}$ saturation ( $\mathrm{Ca} \mathrm{Sat}$ ), $\mathrm{Mg}$ saturation (Mg Sat), K saturation (K Sat), acidity saturation (A Sat), Ca $\mathrm{Mg}^{-1}, \mathrm{Ca} \mathrm{K}{ }^{-1}, \mathrm{Mg} \mathrm{K}^{-1}$ and $(\mathrm{Ca}+\mathrm{Mg}) \mathrm{K}^{-1}$ ratios. Most soil analyses were performed at the 'Centro de Investigaciones Agronómicas', University of Costa Rica ('CIA-UCR'), where $\mathrm{pH}$ was determined in water $10: 25$, available $\mathrm{Ca}, \mathrm{Mg}$ and acidity were measured using $\mathrm{KCl}$ solution $1 \mathrm{M}$ in the ratio $1: 10$ and available $\mathrm{K}$ and $\mathrm{P}$ were analysed with a modified Olsen solution $\mathrm{pH} 8.5\left(\mathrm{NaHCO}_{3} \quad 0.5 \mathrm{~N}\right.$, EDTA $0.01 \mathrm{M}$, Superfloc 127) in $1: 10$ ratio. This methodology is commonly known in Central America as 'modified Olsen-KCl' and is established as a routine activity in the internationally certified CIA-UCR laboratory. Some of the soil samples from Panama were analysed in the Tropical Agricultural Research and Higher Education Center (CATIE) using the same methodology. For the samples from Guatemala and some of the ones from Panama, $\mathrm{pH}$ was determined in water $10: 25$, and the other elements were analysed using the Mehlich 3 extractant (Mehlich 1984). To make the results obtained by Mehlich 3 compatible with those obtained by modified Olsen- $\mathrm{KCl}$, the following 
transformations were used, based on the models proposed by Cabalceta (1995) and Bertsch et al. (2005):

$$
\begin{array}{r}
\mathrm{Ca}_{(\text {Olsen-KCl })}=(1 / 1.05) \cdot \mathrm{Ca}_{(\text {Mehlich3 })}\left[R^{2}=0.95\right] \\
\mathrm{K}_{(\text {Olsen-KCl })}=(1 / 1.41) \cdot \mathrm{K}_{(\text {Mehlich3) }}\left[R^{2}=0.94\right] \\
\mathrm{P}_{(\text {Olsen-KCl })}=2.829+0.647 \cdot \mathrm{P}_{(\text {Mehlich3 })}\left[R^{2}=0.69\right]
\end{array}
$$

A Principal Component Analysis (PCA) was performed to assess similarities between sampled sites according to their soil fertility. Prior to performing the PCA, data were centred and standardised using the mean and the standard deviation of each variable. The 684 soil sites were used as rows and the 15 soil fertility variables as columns. A multivariate cluster analysis was carried out to group the soil samples according to their similarities. Complete linkage (or farthest neighbour) hierarchic clustering was performed using Euclidean distance to measure the similarities in soil fertility between the sites and 10 groups were created. R software was used for all the statistical analyses (R Development Core Team 2008). The relationships between the different variables were also graphically explored by plotting each variable against the others.

The critical values reported in the literature were used for soil analysis interpretation: (1) A Sat $=3 \%$ and $\mathrm{Ca}$ Sat $=68 \%$ (Alvarado and Fallas 2004); (2) K Sat $=3.09 \%$ (J. FernándezMoya A. Alvarado, J. M. Verjans, A. San Miguel-Ayanz, M. Marchamalo-Sacristán, unpubl. data); and (3) the general values used in Costa Rica for the rest of the variables (Bertsch 1998) (Table 1). In addition, some critical values were used based on the experience of the authors in analysing soil fertility in teak plantations throughout the region: $\mathrm{Ca}=10 \mathrm{cmol}(+) \mathrm{L}^{-1}$, $\mathrm{Mg}=3 \mathrm{cmol}(+) \mathrm{L}^{-1}$ and $\mathrm{P}=5 \mathrm{mg} \mathrm{L}^{-1}$ (Table 1).

\section{Results and discussion}

The PCA results revealed a predictable antagonism between $\mathrm{Ca}-$ driven soil attributes with respect to acidity and A Sat, $\mathrm{Mg}, \mathrm{Mg}$ Sat, K, K Sat and P (Fig. 2). Forest managers in the region often form generalised ideas about certain countries or regions having better soils than others. However, the multivariate analysis did not show any noticeable differences either between the countries analysed (Fig. 2) or between regions within each country. Conversely, the multivariate analysis revealed high variability within each region in the form of a soil-fertility gradient. However, soils in Panama are more likely to show acidity problems (low $\mathrm{pH}$ and $\mathrm{Ca}$ Sat, and high acidity and A Sat) whereas they generally have slightly higher P content (Table 1, Fig. 3). Soils from Costa Rica and Guatemala are rather similar, the soils from Guatemala showing somewhat lower $\mathrm{Mg}$ content than those from Costa Rica, which might result in Mg deficiency and differences in the cation balances (Table 1, Fig. 3). Similar K values were found in the three countries, the absolute values generally being adequate although $\mathrm{K}$ sat values were low as the soils are very rich in $\mathrm{Ca}$ and $\mathrm{Mg}$, inducing a generalised $\mathrm{K}$ deficiency (Table 1, Fig. 3).

Although teak is considered a calciphile species, it has been planted at sites throughout Central America with a wide range of soil $\mathrm{pH}$ values (3.6-8.4, Table 1). The findings of a worldwide analysis by Ombina (2008) also reflect this situation (soil pH values 3.8-7.9). As expected, the results of the present study show that $\mathrm{pH}$ can be used as a general indicator of the Ca-acidity relationship in the analysed soils, as acidity saturation falls to values below 3\% (critical level for the species, according to Alvarado and Fallas 2004) in soils with $\mathrm{pH}$ values higher than 5.5, sharply increasing in soils with lower $\mathrm{pH}$ (Fig. 3). This tendency is in accordance with the classical theory regarding soil acidity in tropical regions (e.g. Kamprath 1984). Accordingly, soils with $\mathrm{pH}$ lower than 5.5 are more likely to have low $\mathrm{Ca}$ Sat and show high $\mathrm{Mg}$ Sat, while soils with $\mathrm{pH}$ higher than 5.5 generally have $\mathrm{Ca}$ Sat values higher than $68 \%$ (critical level for the species, Alvarado and Fallas 2004). Although cation saturation index varies according to ECEC values and the general soil cation balance, when $\mathrm{Ca}$ content is higher than $20-25 \mathrm{cmol}(+) \mathrm{L}^{-1}$, the cases of A Sat problems seem to be less common (Fig. 3). However, high $\mathrm{Ca}$ values can also be a problem, as available $\mathrm{P}$ content decrease when $\mathrm{Ca}$ exceeds levels of around $50-60 \mathrm{cmol}^{(+)} \mathrm{L}^{-1}$ (Fig. 3), probably because $\mathrm{P}$ would be precipitated as Ca phosphates. Similarly, P content is higher where there is no noticeable soil acidity problem $\left(<0.5 \mathrm{cmol}(+) \mathrm{L}^{-1}\right)$ and $\mathrm{P}$ availability becomes a problem when acidity is high $\left(>2.5 \mathrm{cmol}(+) \mathrm{L}^{-1}\right)$ (Fig. 3), probably because $\mathrm{P}$ would be precipitated as $\mathrm{Al}$ and/or Fe phosphates.

The 684 soil samples were divided into 10 groups according to their similarities with regards to soil fertility using cluster analysis (Table 2). Most groups showed a $\mathrm{K}$ deficiency (K Sat $<3.09 \%$ ) except G-6, G-9 and G-10, the latter being the only group with no soil fertility problems although it only comprised 10 samples (Table 2). G-6 only had slight problems of acidity, whereas G-9 had problems of acidity as well as available $\mathrm{Ca}$ and $\mathrm{Mg}$ (Table 2). Despite K deficiency, G-2 had generally adequate cation values although their $\mathrm{P}$ content might be in the critical range, as with the G-8 samples, although this group also showed a slightly lower Mg content. The other groups (G-1, G-3, G-4, G-5 and G-7) presented different combinations of nutrient deficiencies and toxicities, which in simple terms can be described as low soil fertility (Table 2).

Teak is considered to be a species with high soil nutrient requirements; deep, well drained soils with high chemical fertility (especially $\mathrm{Ca}$ ) and low acidity are usually considered necessary for the successful growth of this species (Montero 1999; Alvarado and Fallas 2004; Mollinedo et al. 2005; Kumar 2011; Alvarado 2012). However, teak plantations are found on a wide variety of soils, including many with serious problems of fertility (e.g. Ultisols and Oxisols) or with added difficulties due to their physical properties (e.g. Vertisols) (Zech and Drechsel 1991; Drechsel and Zech 1994; Ombina 2008; Kumar 2011; Alvarado 2012). The soils analysed in the present study also showed high variability, including Inceptisols, Entisols, Vertisols, Andisols, Alfisols, Ultisols and perhaps Oxisols. The wide variety of soil fertility levels in teak plantations of Central America has also been observed in Africa. Ombina (2008) reported teak plantations on low fertility soils in Southern Sudan, Zech and Drechsel (1991) found generally deficient soils in Liberia, while Adekunle et al. (2011) described relatively high fertility soils in Nigeria. Similarly, Drechsel and Zech (1994) found a variety of rich and poor soils in Togo, Benin, Côte d'Ivoire, Liberia and Nigeria. Asian teak plantations have also been established on a wide variety of soils (Kumar 2011). 
Table 1. Summary of the soil fertility variables analysed in teak (Tectona grandis L.f.) plantations in Central America: Costa Rica, Guatemala and Panama

Mean, Confidence Interval at 95\% ('CI') and range (minimum-maximum) are reported for each variable considering a country average. Critical values for some of the variables are reported either from literature (Bertsch 1998; Alvarado and Fallas 2004; J. Fernández-Moya, A. Alvarado, J. M. Verjans, A. San MiguelAyanz, M. Marchamalo-Sacristán, unpubl.) or based on the experience of the authors. Problematic values according to those critical values are remarked in red bold type when it does not match either the literature or the empirical critical values and orange bold type when it is adequate taking one of them into consideration. ECEC, Effective Cation Exchange Capacity $[\mathrm{ECEC}=$ Acidity $+\mathrm{Ca}+\mathrm{Mg}+\mathrm{K}] ; \mathrm{Ca}$ Sat, Ca saturation $[\mathrm{Ca} \mathrm{Sat}=\mathrm{Ca} / \mathrm{ECEC}] ; \mathrm{Mg} \mathrm{Sat}, \mathrm{Mg}$ saturation $[\mathrm{Mg} \mathrm{Sat}=\mathrm{Mg} / \mathrm{ECEC}]$; K Sat, K saturation $[\mathrm{K} \mathrm{Sat}=\mathrm{K} / \mathrm{ECEC}]$; A Sat, Acidity saturation $[\mathrm{A} \mathrm{Sat}=$ Acidity/ECEC]

\begin{tabular}{|c|c|c|c|c|c|c|c|}
\hline & & Regional & Costa Rica & Guatemala & Panama & & values \\
\hline & & $(n=684)$ & $(n=299)$ & $(n=257)$ & $(n=128)$ & Literature & $\begin{array}{l}\text { Experience } \\
\text { of the authors }\end{array}$ \\
\hline $\mathrm{pH}$ & $\begin{array}{l}\text { Mean } \\
\text { CI } \\
\text { Range }\end{array}$ & $\begin{array}{c}6.0 \\
(5.9,6.0) \\
3.6-8.4\end{array}$ & $\begin{array}{c}5.9 \\
(5.9,6.0) \\
4.4-7.8\end{array}$ & $\begin{array}{c}6.6 \\
(6.5,6.7) \\
4.2-8.4\end{array}$ & $\begin{array}{c}4.8 \\
(4.7,4.9) \\
3.6-7.6\end{array}$ & 5.5 & - \\
\hline $\mathrm{Ca}\left(\operatorname{cmol}(+) \mathrm{L}^{-1}\right)$ & $\begin{array}{l}\text { Mean } \\
\text { CI } \\
\text { Range }\end{array}$ & $\begin{array}{c}20.4 \\
(19.2,21.7) \\
0.7-143.9\end{array}$ & $\begin{array}{c}25.3 \\
(24.1,26.6) \\
1.2-59.9\end{array}$ & $\begin{array}{c}19.7 \\
(17.1,22.4) \\
0.7-143.9\end{array}$ & $\begin{array}{c}10.5 \\
(9.2,11.7) \\
1.2-43.6\end{array}$ & 4.0 & 10.0 \\
\hline $\operatorname{Mg}\left(\operatorname{cmol}(+) L^{-1}\right)$ & $\begin{array}{l}\text { Mean } \\
\text { CI } \\
\text { Range }\end{array}$ & $\begin{array}{c}5.7 \\
(5.3,6.1) \\
0.2-33.5\end{array}$ & $\begin{array}{c}7.8 \\
(7.3,8.3) \\
0.5-23.4\end{array}$ & $\begin{array}{c}2.1 \\
(1.8,2.4) \\
0.2-16.5\end{array}$ & $\begin{array}{c}8.1 \\
(7.1,9.0) \\
1.0-33.5\end{array}$ & 1.0 & 3.0 \\
\hline $\mathrm{K}\left(\operatorname{cmol}(+) \mathrm{L}^{-1}\right)$ & $\begin{array}{l}\text { Mean } \\
\text { CI } \\
\text { Range }\end{array}$ & $\begin{array}{c}0.3 \\
(0.3,0.3) \\
0-3\end{array}$ & $\begin{array}{c}0.3 \\
(0.3,0.4) \\
0-3\end{array}$ & $\begin{array}{c}0.3 \\
(0.2,0.3) \\
0-1.9\end{array}$ & $\begin{array}{c}0.4 \\
(0.3,0.4) \\
0-1.6\end{array}$ & 0.2 & - \\
\hline Acidity $\left(\operatorname{cmol}(+) L^{-1}\right)$ & $\begin{array}{l}\text { Mean } \\
\text { CI } \\
\text { Range }\end{array}$ & $\begin{array}{c}0.6 \\
(0.5,0.7) \\
0-18.8\end{array}$ & $\begin{array}{c}0.3 \\
(0.3,0.4) \\
0.1-6.4\end{array}$ & $\begin{array}{c}0.2 \\
(0.1,0.3) \\
0-10.1\end{array}$ & $\begin{array}{c}2.0 \\
(1.4,2.6) \\
0.1-18.8\end{array}$ & 0.5 & - \\
\hline $\operatorname{ECEC}\left(\operatorname{cmol}(+) \mathrm{L}^{-1}\right)$ & $\begin{array}{l}\text { Mean } \\
\text { CI } \\
\text { Range }\end{array}$ & $\begin{array}{c}27.0 \\
(25.7,28.4) \\
1.6-149.5\end{array}$ & $\begin{array}{c}33.8 \\
(32.2,35.3) \\
4.7-80.2\end{array}$ & $\begin{array}{c}22.3 \\
(19.6,25.0) \\
1.6-149.5\end{array}$ & $\begin{array}{c}20.9 \\
(18.9,22.9) \\
3.8-69.5\end{array}$ & $\begin{array}{l}- \\
-\end{array}$ & $\begin{array}{l}- \\
-\end{array}$ \\
\hline Ca Sat (\%) & $\begin{array}{l}\text { Mean } \\
\text { CI } \\
\text { Range }\end{array}$ & $\begin{array}{c}73.3 \\
(72.0,74.6) \\
14.9-98.8\end{array}$ & $\begin{array}{c}74.0 \\
(73.0,75.1) \\
17.3-97.5\end{array}$ & $\begin{array}{c}84.3 \\
(82.6,85.9) \\
14.9-98.8\end{array}$ & $\begin{array}{c}49.6 \\
(47.2,52.0) \\
21.4-84.3\end{array}$ & 68.0 & - \\
\hline Mg Sat (\%) & $\begin{array}{l}\text { Mean } \\
\text { CI } \\
\text { Range }\end{array}$ & $\begin{array}{c}21.5 \\
(20.6,22.5) \\
0.7-70.2\end{array}$ & $\begin{array}{c}22.9 \\
(22.0,23.7) \\
1.6-45.2\end{array}$ & $\begin{array}{c}11.9 \\
(10.7,13.2) \\
0.7-70.2\end{array}$ & $\begin{array}{c}37.8 \\
(35.8,39.8) \\
12.8-67.8\end{array}$ & - & - \\
\hline K Sat (\%) & $\begin{array}{l}\text { Mean } \\
\text { CI } \\
\text { Range }\end{array}$ & $\begin{array}{c}1.6 \\
(1.4,1.7) \\
0-16.5\end{array}$ & $\begin{array}{c}1.1 \\
(1.0,1.3) \\
0.1-9.0\end{array}$ & $\begin{array}{c}1.9 \\
(1.6,2.1) \\
0-16.5\end{array}$ & $\begin{array}{c}2.0 \\
(1.8,2.2) \\
0.1-5.3\end{array}$ & 3.09 & - \\
\hline A Sat (\%) & $\begin{array}{l}\text { Mean } \\
\text { CI } \\
\text { Range }\end{array}$ & $\begin{array}{c}3.6 \\
(2.9,4.3) \\
0-72.9\end{array}$ & $\begin{array}{c}2.0 \\
(1.3,2.7) \\
0.1-60.5\end{array}$ & $\begin{array}{c}1.9 \\
(1.0,2.8) \\
0-72.9\end{array}$ & $\begin{array}{c}10.6 \\
(8.3,13.0) \\
0.2-64.5\end{array}$ & 3.0 & - \\
\hline $\mathrm{Ca} \mathrm{Mg}{ }^{-1}$ & $\begin{array}{l}\text { Mean } \\
\text { CI } \\
\text { Range }\end{array}$ & $\begin{array}{c}7.4 \\
(6.5,8.3) \\
0.3-137.7\end{array}$ & $\begin{array}{c}4.2 \\
(3.7,4.8) \\
0.8-62.7\end{array}$ & $\begin{array}{c}14.0 \\
(12.1,16.0) \\
0.4-137.7\end{array}$ & $\begin{array}{c}1.5 \\
(1.4,1.6) \\
0.3-6.5\end{array}$ & - & - \\
\hline $\mathrm{Ca} \mathrm{K}^{-1}$ & $\begin{array}{l}\text { Mean } \\
\text { CI } \\
\text { Range }\end{array}$ & $\begin{array}{c}147.3 \\
(131.6,163.0) \\
3.2-1926.2\end{array}$ & $\begin{array}{c}213.2 \\
(187.4,238.9) \\
7-1518.5\end{array}$ & $\begin{array}{c}119.1 \\
(93.5,144.8) \\
3.2-1926.2\end{array}$ & $\begin{array}{c}50.1 \\
(38.6,61.7) \\
9.2-361.4\end{array}$ & - & - \\
\hline $\mathrm{Mg} \mathrm{K}^{-1}$ & $\begin{array}{l}\text { Mean } \\
\text { CI } \\
\text { Range }\end{array}$ & $\begin{array}{c}44.2 \\
(39.0,49.3) \\
0.7-493.2\end{array}$ & $\begin{array}{c}71.7 \\
(62.2,81.1) \\
1.8-492.8\end{array}$ & $\begin{array}{c}14.2 \\
(10.8,17.7) \\
0.7-340.5\end{array}$ & $\begin{array}{c}40.0 \\
(29.1,50.8) \\
5.5-493.2\end{array}$ & - & - \\
\hline$(\mathrm{Ca}+\mathrm{Mg}) \mathrm{K}^{-1}$ & $\begin{array}{l}\text { Mean } \\
\text { CI } \\
\text { Range }\end{array}$ & $\begin{array}{c}191.5 \\
(171.7,211.3) \\
4-2119.1\end{array}$ & $\begin{array}{c}284.8 \\
(250.2,319.4) \\
9.6-1981.5\end{array}$ & $\begin{array}{c}133.4 \\
(105.5,161.3) \\
4-2119.1\end{array}$ & $\begin{array}{c}90.1 \\
(68.8,111.5) \\
16.2-752.8\end{array}$ & - & - \\
\hline $\mathrm{P}\left(\mathrm{mg} \mathrm{L}^{-1}\right)$ & $\begin{array}{l}\text { Mean } \\
\text { CI } \\
\text { Range }\end{array}$ & $\begin{array}{c}7.9 \\
(7.1,8.7) \\
0-78.6\end{array}$ & $\begin{array}{c}7.6 \\
(5.9,9.2) \\
0-78.0\end{array}$ & $\begin{array}{c}8.1 \\
(7.2,8.9) \\
2.8-78.6\end{array}$ & $\begin{array}{c}8.5 \\
(7.5,9.5) \\
0.1-20.1\end{array}$ & 10.0 & 5.0 \\
\hline
\end{tabular}




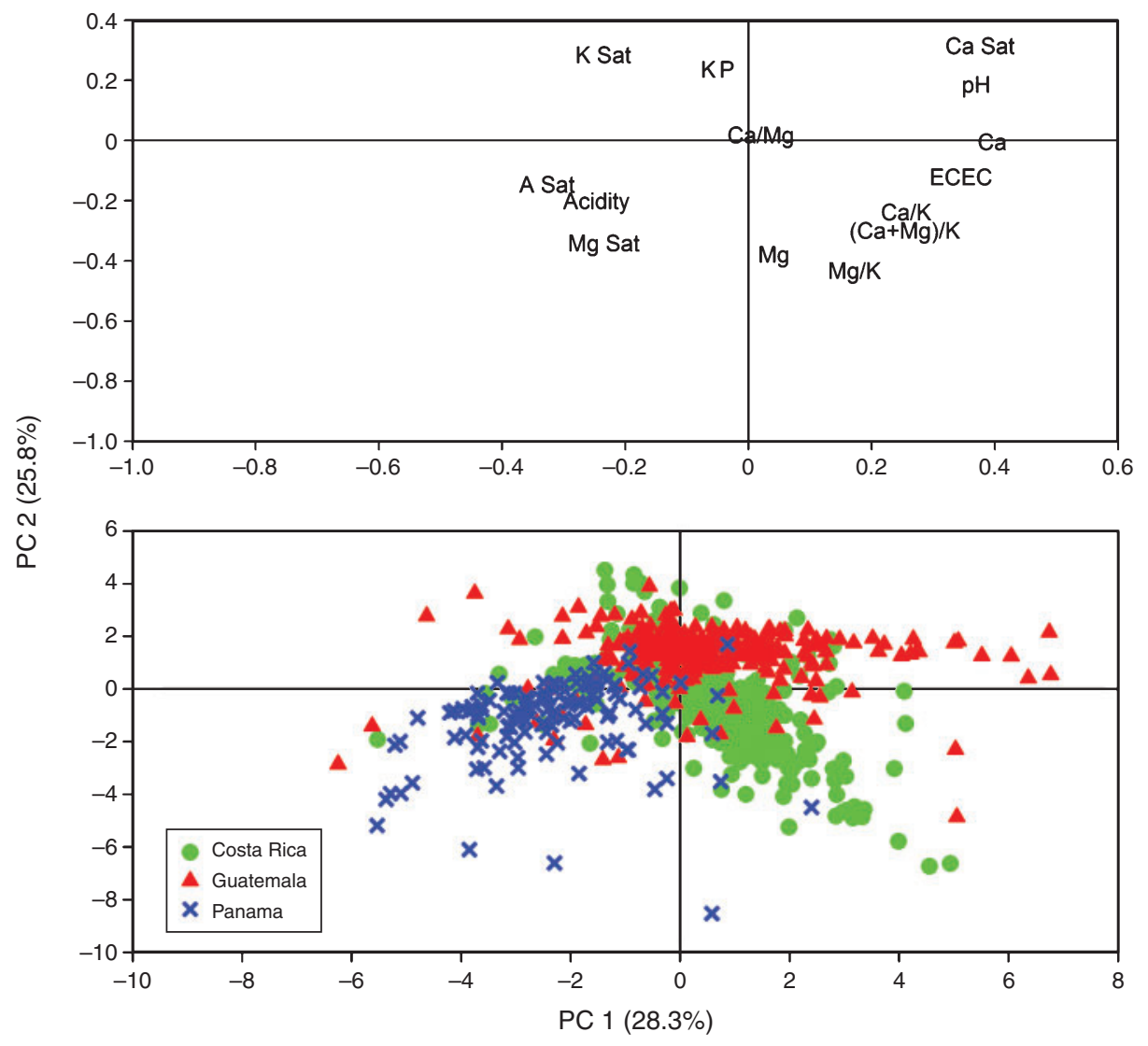

Fig. 2. Results of the PCA of the 684 soil samples according to the 15 soil fertility variables analysed in teak (Tectona grandis L.f.) plantations in Central America: Costa Rica, Guatemala and Panama.

Despite the commonly high nutrient requirements of the species and the general belief that soils under teak plantations tend to be fertile, our data reveals that most sites in Central America exhibit soil deficiencies of some kind, especially related to $\mathrm{K}$, acidity and $\mathrm{P}$ (Tables 1 and 2, Fig. 3). Site selection based on soil fertility was not a widespread practice when the first large teak plantations of the region were established in the 1980s. Although several protocols were later developed (Keogh 1987; Müller et al. 1998; Núñez 2001), many teak plantations of the 1980s and 1990s were established on poor sites due to corruption, technical negligence and/or administrative problems. Poor site selection is considered one of the causes of the failure of several financial investments based on plantations in Central America. These failures have left Central American plantations with a poor reputation in certain countries (e.g. the Netherlands), where many people lost their savings after investing in plantations, which were sold as financial products with expected high rates of return and that did not live up to expectations. Numerous sites in the northern lowlands of Costa Rica, which were acquired for teak plantations had soil fertility and/or physical problems (e.g. shallow soils with bad drainage and plinthite), leading to dieback syndrome in the following years (Arguedas et al. 2009), even though the soils were considered adequate at the time and high teak growth was anticipated. Similarly, many of the initial teak plantations in Guatemala were established on sites with poor soils, although since the implementation of the site selection protocol (Segura et al. 2013) the soil quality at recently acquired sites has improved. Despite the fact that soil fertility is carefully evaluated in most teak plantations established today, it seems that managers still have to deal with soil fertility deficiencies (particularly as regards $\mathrm{K}$, acidity and $\mathrm{P}$ ) at many sites acquired several years ago.

Fernández-Moya et al. (2014) already highlighted the importance of $\mathrm{K}$ and $\mathrm{P}$ in teak plantations in Central America, as the accumulation in tree tissues and exporting of both elements through timber harvesting is very high in relation to the amounts available in the soil. In addition, FernándezMoya et al. (J. Fernández-Moya, A. Alvarado, J. M. Verjans, A. San Miguel-Ayanz, M. Marchamalo-Sacristán, unpubl. data) state that $\mathrm{P}$ and $\mathrm{K}$ deficiencies are directly related to a decrease in teak performance in Panama. However, the underlying cause may not be $\mathrm{K}$ deficiency but rather a problem of cationic unbalance due to the high values of $\mathrm{Ca}$ and/or $\mathrm{Mg}$ (Tables 1 and 2). Two further problems exist with regard to $\mathrm{K}$ management in the studied systems: (i) susceptibility to leaching due to the high levels of precipitation throughout the study area; and (ii) fixation, especially if the soil mineralogy is dominantly vermiculite, abundant in many soils in the region considered as highly fertile. In addition, $\mathrm{Mg}$ deficiencies have been observed by forest managers in the field, although this is not reflected by the results of the present study. 

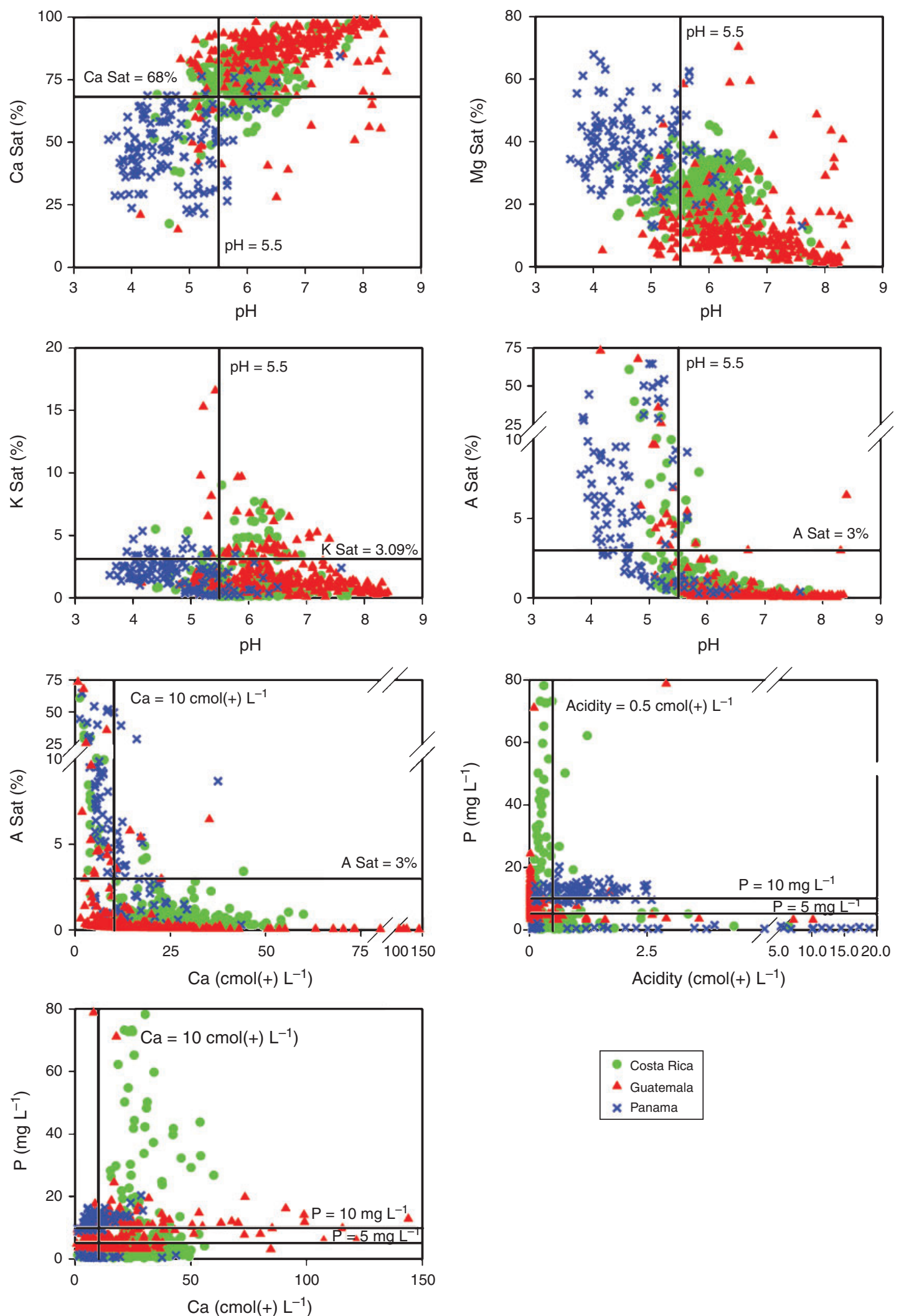

Fig. 3. Relationship between some of the soil fertility variables analysed in teak (Tectona grandis L.f.) plantations in Central America: Costa Rica, Guatemala and Panama. 


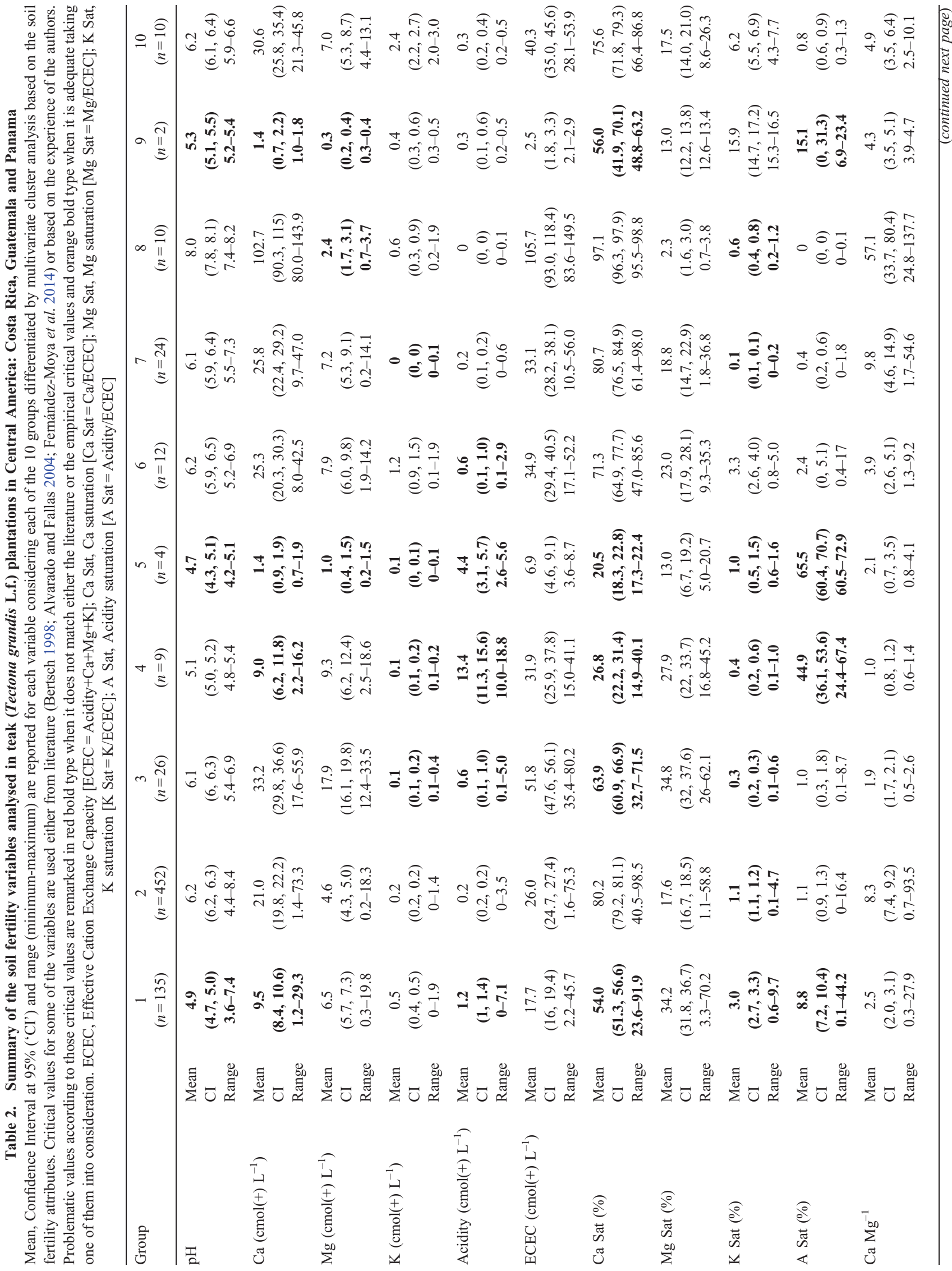




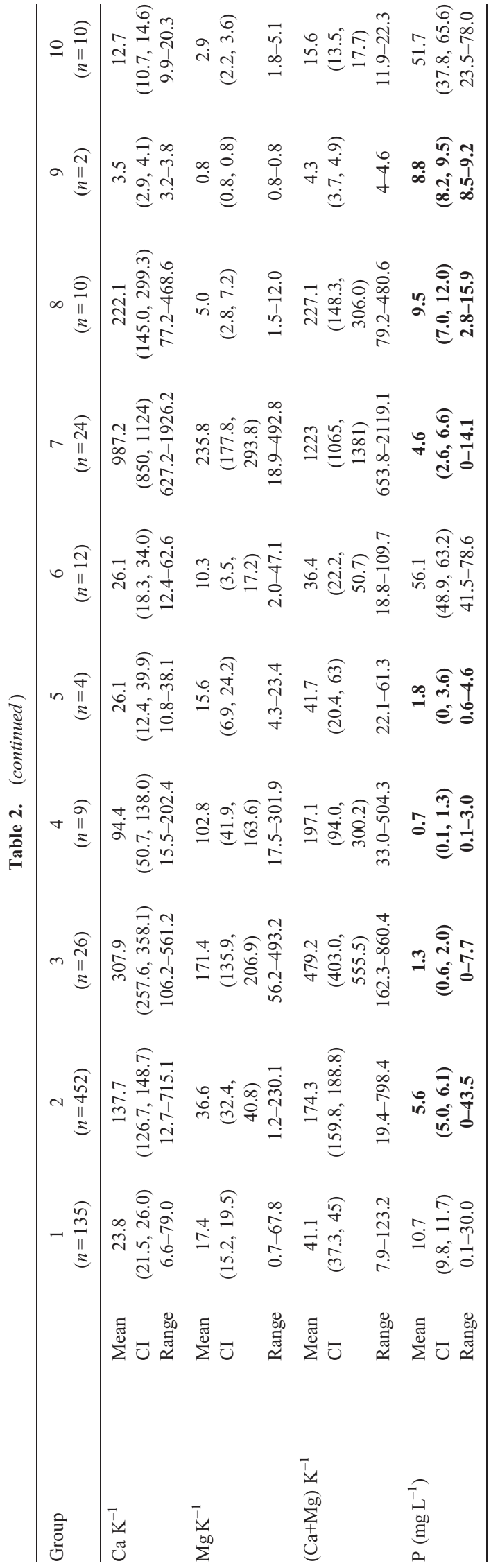

Although some high available $\mathrm{P}$ values are found, the results show a general $\mathrm{P}$ deficiency in the soils under teak plantations in the region. Most of the P rich sites probably result from a residual effect of the fertilizer applied during the previous land use. This is especially common in Guatemala, where teak plantations have commonly been established on sites previously used for agriculture (e.g. maize), whereas in Costa Rica and Panama, they have generally been established on former grasslands. Phosphorus is recognised as an important limiting nutrient in forest plantations (Fox et al. 2011) and is considered to be generally deficient in tropical forests, which is why tropical tree species are usually P-efficient (Vitousek 1984; Hedin et al. 2009). Although P fertilisation is usually considered to be a requirement, especially in large-scale plantations, the presence of mycorrhizas has been identified as necessary for the production of phosphatases (Corryanti et al. 2007), which improve the mineralisation rates of organic- $\mathrm{P}$, resulting in higher levels of available P. Alvarado et al. (2004) collected mycorrhizas in teak plantations throughout Costa Rica and proposed the inoculation of seedlings as a way to improve $\mathrm{P}$ uptake and enhance productivity, particularly in acid soils.

Many authors have reported soil acidity-toxicity problems in teak plantations (e.g. Zech and Drechsel 1991; Drechsel and Zech 1994; Wehr 2010; Zhou et al. 2012) and liming is recommended when A Sat is higher than 3\% (Alvarado and Fallas 2004). Although large investors now take into account soil requirements and the poor adaptation of teak to acid soils when acquiring land for establishing new plantations, many small-landowners cannot afford to pay the prices demanded for agricultural land and have to make do with the land they already own, which in many cases presents low soil fertility and acidity problems (e.g. red acidic Ultisols). The establishment of teak plantations on this marginal land is a mistake that has been frequently made. Moreover it has been found that in some cases the establishment of native species such as Terminalia amazonia and Swietenia macrophylla could be more profitable than teak plantations (Griess and Knoke 2011).

Despite their importance to forest growth, the present study cannot take into consideration either physical soil properties or micronutrient availability due to the shortage of data. Within a small region with a homogeneous climate, several variables such as bulk density, water retention capacity or the position on the slope can affect the amount of available water in a given plot over the course of the year. Similarly, large amounts of certain micronutrients can be found in teak biomass (Fernández-Moya et al. 2014) and despite a lack of concern with respect to this circumstance, it may imply (1) a hidden soil fertility deficiency; and (2) a problem in future rotations.

\section{Conclusions}

The present work provides a global framework to help contextualise the soil fertility analyses conducted at subregional or farm level. The soils analysed in the present study showed high variability, including Inceptisols, Entisols, Vertisols, Andisols, Alfisols, Ultisols and perhaps Oxisols. Although high soil fertility is often assumed in teak 
plantations, our results show a general $\mathrm{K}$ deficiency in the Central American teak plantations, where $\mathrm{P}$ deficiency and acidity-toxicity are also relatively common problems. These soil fertility problems are often the result of poor site selection by forest managers in the 1980s and 1990s. Hence, although soil fertility is carefully evaluated when most teak plantations are established today, managers have to deal with soil fertility deficiencies at many sites where teak was established some years ago. Further research regarding teak nutrition in Central America should also consider including physical soil properties and micronutrients in order to carry out a more detailed analysis.

\section{Acknowledgements}

The authors would like to acknowledge the collaboration of several forest companies for their collaboration sharing the soil data for the present work: Ecoforest Ltd, Panamerican Woods Ltd and Green Millenium Ltd The authors also thank Adam Collins and the personnel of the Natural Resources Laboratory at CIA (UCR) for their help and comments about English language, manuscript format and for their assistance about the contents of this paper. The present paper was conducted under the MACOSACEN project, financed by PCI-AECID.

\section{References}

Adekunle V, Alo A, Adekayode F (2011) Yields and nutrient pools in soils cultivated with Tectona grandis and Gmelina arborea in Nigerian rainforest ecosystem. Journal of the Saudi Society of Agricultural Sciences 10, 127-135. doi:10.1016/j.jssas.2011.05.001

Alvarado A (2012) Nutrición y fertilización de Tectona grandis Linn. f. In 'Nutrición y fertilización forestal en regiones tropicales'. (Eds A Alvarado, J Raigosa) pp. 313-340. (Asociación Costarricense de las Ciencias del Suelo: San José, Costa Rica)

Alvarado A, Fallas JL (2004) La saturación de acidez y el encalado sobre el crecimiento de la teca (Tectona grandis L.f.) en suelos ácidos de Costa Rica. Agronomía Costarricense 28, 81-87.

Alvarado A, Chavarría M, Guerrero R, Boniche J, Navarro JR (2004) Características edáficas y presencia de micorrizas en plantaciones de teca (Tectona grandis L.f.) en Costa Rica. Agronomía Costarricense 28, 89-100.

Arguedas M, Arias D, Mata R, Herrera W, Calvo J (2009) Síndrome del decaimiento lento de la teca (SDLT) en Costa Rica. Kurú, Revista Forestal Centroamericana 6, 2.

Arias G (2004) 'Análisis del impacto económico y social de las plantaciones forestales en Costa Rica.' (FUNDECOR: San José, Costa Rica)

Bertsch F (1998) 'La fertilidad de los suelos y su manejo.' (Asociación Costarricense de la Ciencia del Suelo: San José, Costa Rica)

Bertsch F, Bejarano JA, Corrales M (2005) Correlación entre las soluciones extractoras KCl-Olsen modificado y Mehlich 3, usadas en los laboratorios de suelos de Costa Rica. Agronomía Costarricense 29, 137-142.

Cabalceta G (1995) Correlación de soluciones extractoras de fósforo en suelos de Costa Rica. Agronomía Costarricense 19, 29-37.

Corryanti JS, Radjagukguk B, Widyastuti SM (2007) Phosphatase activity in the rhizosphere and root of mycorrhizal teak seedlings with three levels of NPK fertilization. Biodiversitas 8, 204-209. doi:10.13057/ biodiv/d080308

De Camino R, Alfaro M, Sage L, Varmola M (2002) 'Teak (Tectona grandis) in Central America.' (Forestry Department, FAO: Rome)

Drechsel P, Zech W (1994) DRIS evaluation of teak (Tectona grandis L.f.) mineral nutrition and effects of nutrition and site quality on teak growth in West Africa. Forest Ecology and Management 70, 121-133. doi:10.1016/0378-1127(94)90080-9

Fernández-Moya J, Murillo R, Portuguez E, Fallas JL, Ríos V, Kottman K, Verjans JM, Mata R, Alvarado A (2014) Nutrient accumulation and export in teak (Tectona grandis L.f.) plantations in Central America. iForest 8, 33-44. doi:10.3832/ifor1089-007

Fox TR, Miller BW, Rubilar R, Stape JL, Albaugh TJ (2011) Phosphorus nutrition of forest plantations: The role of inorganic and organic phosphorus. In 'Phosphorus in action'. (Eds E Büneman, A Oberson, E Frossard) pp. 317-338. (Springer: Berlin, Heidelberg)

Griess VC, Knoke T (2011) Can native tree species plantations in Panama compete with Teak plantations? An economic estimation. New Forests 41, 13-39. doi:10.1007/s11056-010-9207-y

Hedin LO, Brookshire EJ, Menge DN, Barron AR (2009) The nitrogen paradox in tropical forest ecosystems. Annual Review of Ecology, Evolution and Systematics 40, 613-635. doi:10.1146/annurev.ecolsys. 37.091305 .110246

Holdridge LR (1967) 'Life zone ecology.' (Tropical Science Center: San José, Costa Rica)

Kamprath EJ (1984) Crop response to lime on soils in the tropics. In 'Soil acidity and liming'. (Ed. F Adams) pp. 349-369. (American Society of Agronomy: Madison, WI, USA)

Keogh R (1987) 'The care and management of teak (Tectona grandis L.f.) plantations.' (Universidad Nacional de Costa Rica: Heredia, Costa Rica)

Kollert W, Cherubini L (2012) 'Teak resources and market assessment 2010.' FAO Planted Forests and Trees Working Paper FP/47/E. (FAO: Rome)

Kumar BM (2011) Soil management in teak plantations. In 'Proceedings of the International Training Programme Innovations in the Management of Planted Teak Forests'. (Eds K Jayaraman, KV Bhat) pp. 24-30. (TEAKNET/Kerala Forest Research Institute: Peechi, India)

Mehlich A (1984) Mehlich 3 soil test extractant: A modification of Mehlich 2 extractant. Communications in Soil Science and Plant Analysis 15, 1409-1416. doi:10.1080/00103628409367568

Mollinedo M, Ugalde L, Alvarado A, Verjans JM, Rudy LC (2005) Relación suelo-árbol y factores de sitio, en plantaciones jóvenes de teca (Tectona grandis), en la zona oeste de la cuenca del canal de Panamá. Agronomía Costarricense 29, 67-75.

Montero M (1999) Factores de sitio que influyen en el crecimiento de Tectona grandis Lf y Bombacopsis quinata (Jacq.) Dugand, en Costa Rica. MSc Thesis, Universidad Austral de Chile, Valdivia, Chile.

Müller S, Núñez J, Ramírez L (1998) 'Indicadores para el uso de la tierra: el caso de la cuenca del río Reventado, Costa Rica.' (Instituto Interamericano de Cooperación para la Agricultura (IICA): San José, Costa Rica)

Nieuwenhuyse A, Hengsdijk H, Bouman B, Schipper RA, Jansen H (2000) Can forestry be a competitive land use option?: Model simulations from humid tropical Costa Rica. Forest Ecology and Management 137, 23-40. doi:10.1016/S0378-1127(99)00310-2

Núñez J (2001) ‘Criterios edaficos en la seleccion de sitios para teca.' (San José, Costa Rica)

Ombina CA (2008) Soil characterisation for teak (Tectona grandis) plantations in the Nzara district of Southern Sudan. MSc Thesis, Stellenbosch University, Stellenbosch, South Africa.

Pandey D, Brown C (2000) 'Teak: a global overview.' (FAO: Rome)

R Development Core Team (2008) 'R: A language and environment for statistical computing.' (R Foundation for Statistical Computing: Vienna, Austria)

Segura JM, Alvarado A, Vaides EE (2013) 'Clasificación de tierras aptas para el establecimiento de plantaciones forestales de teca (Tectona grandis L. f.) en Petén, Guatemala. In 'VIII Congreso Forestal Centroamericano'. San Pedro Sula, Honduras.

Vitousek PM (1984) Litterfall, nutrient cycling, and nutrient limitation in tropical forests. Ecology 65, 285-298. doi:10.2307/1939481 
Wehr AJB (2010) Aluminum sensitivity and optimum $\mathrm{Ca}$ and $\mathrm{pH}$ requirement of teak (Tectona grandis Linn. f.) clones used for forestry plantations in Australia. In 'Proceedings of the 19th World Congress of Soil Science'. Brisbane, Australia.

Zech W, Drechsel P (1991) Relationships between growth, mineral nutrition and site factors of teak (Tectona grandis) plantations in the rainforest zone of Liberia. Forest Ecology and Management 41, 221-235. doi:10.1016/0378-1127(91)90105-5

Zhou Z, Liang K, Xu D, Zhang Y, Huang G, Ma H (2012) Effects of calcium, boron and nitrogen fertilization on the growth of teak (Tectona grandis) seedlings and chemical property of acidic soil substrate. New Forests 43, 231-243. doi:10.1007/s11056-011-9276-6 